\title{
Chemotherapy-Induced Cognitive Decline: Moving from the Mechanistic Debate towards Prevention and Treatment-A Clinical Review
}

\author{
Roi Tschernichovsky¹, Lauren Philp², Annekathryn Goodman ${ }^{2 *}$ \\ ${ }^{1}$ Institute of Oncology, Davidoff Cancer Center, Beilinson Hospital, Rabin Medical Center, Petach Tikva, Israel \\ ${ }^{2}$ Division of Gynecologic Oncology Massachusetts General Hospital, Boston, MA, USA \\ Email: rtscher@gmail.com, LPHILP@mgh.harvard.edu, *agoodman@mgh.harvard.edu
}

How to cite this paper: Tschernichovsky, R., Philp, L. and Goodman, A. (2019) Chemotherapy-Induced Cognitive Decline: Moving from the Mechanistic Debate towards Prevention and Treatment-A Clinical Review. Journal of Cancer Therapy, 10, 985-1012.

https://doi.org/10.4236/jct.2019.1012084

Received: November 29, 2019

Accepted: December 21, 2019

Published: December 24, 2019

Copyright $\odot 2019$ by author(s) and Scientific Research Publishing Inc. This work is licensed under the Creative Commons Attribution International License (CC BY 4.0).

http://creativecommons.org/licenses/by/4.0/ (c) (i) Open Access

\begin{abstract}
Patients receiving chemotherapy have reported cognitive challenges including short-term memory loss and reduced executive functioning. While cognitive decline can be multifactorial and related to aging, depression, surgery, and other medications, there has been a steadily increasing body of knowledge showing a significant association between cognitive decline and chemotherapy administration. This clinical review summarizes patient-reported cognitive changes, support from neuroimaging and neuropsychological testing. The mechanism of action of and patient susceptibilities to cognitive decline are reviewed. Current behavioral and pharmacologic interventions are discussed. There is a need to identify patients at risk for developing chemotherapy induced cognitive decline and to screen for early signs of cognitive deterioration. The risk of cognitive dysfunction and possible interventions should be included in the informed consent discussion with patients who are undergoing cytotoxic treatments.
\end{abstract}

\section{Keywords}

Chemotherapy, Cognitive Decline, Cognitive Impairment, Chemo-Brain, Chemo-Fog, Cancer Survivorship, Quality of Life

\section{Introduction}

Recent advances in the diagnosis and treatment of cancer have led to an increased number of patients entering survivorship [1] [2]. Increased survival rates dictate that more resources should be directed towards diagnosing and managing the issues affecting patients' post-treatment quality of life. Among these, 
chemotherapy-induced cognitive decline (CICD) has emerged as an important sequelae of therapy.

The paramount challenge in any discussion of CICD is discerning the potential cognitive harms of cytotoxic drugs from an assortment of possible confounders, including age-related cognitive deterioration, the adverse effects of concurrent treatment modalities, and disease-related factors stemming from the cancer itself (Table 1) [3]-[19]. For instance, long-term adjuvant endocrine therapy (ET) is a standard treatment for hormone-positive breast cancer (BC) and is a plausible etiology for cognitive dysfunction in treated women [4] [5] [6]. While some studies have reported ET-related cognitive impairments over a short-term follow-up period, a recent longitudinal study which observed ET-treated patients for up to six years failed to demonstrate such an association [7]. Major oncological surgery is another candidate mechanism, with data showing post-surgical cognitive decline in a substantial percentage of patients, most notably in elderly populations [8]. Chronic opioid usage for management of cancer-related pain is similarly associated with cognitive deficits in a dose-related manner [9].

Table 1. Evidence for possible culprits responsible for cognitive decline in cancer patients, other than chemotherapy.

\begin{tabular}{|c|c|c|c|c|}
\hline Cluster & Etiology & Reference & Study Design & Findings \\
\hline \multirow{3}{*}{ Iatrogenic } & $\begin{array}{l}\text { Long-term adjuvant } \\
\text { endocrine therapy }\end{array}$ & Van Dyke, et al. [7] & $\begin{array}{l}\text { Prospective } \\
\text { longitudinal }\end{array}$ & $\begin{array}{l}\text { No association found between long-term endocrine } \\
\text { therapy and neurocognitive performance }\end{array}$ \\
\hline & Major oncologic surgery & Plas $M$, et al. [8] & $\begin{array}{l}\text { Prospective } \\
\text { longitudinal }\end{array}$ & $\begin{array}{l}\text { - } 12 \% \text { of patients overall exhibit cognitive decline } \\
\text { at } 3 \text {-months following major oncologic surgery } \\
\text { - } 18 \% \text { of patients aged }>75 \text { years exhibit cognitive } \\
\text { decline at } 3 \text { months following major oncologic } \\
\text { surgery }\end{array}$ \\
\hline & Chronic opioid usage & Kurita GP, et al. [9] & $\begin{array}{l}\text { Prospective } \\
\text { cross-sectional, } \\
\text { multi-center }\end{array}$ & $\begin{array}{l}\text { A third of opioid-treated patients exhibit } \\
\text { possible }\left(\mathrm{MMSE}^{\mathrm{a}} \text { score } 24 \text { - 26) or definite }\right. \\
\text { (MMSE score }<24) \text { cognitive dysfunction } \\
\text { - Patients receiving daily dose of } 400 \mathrm{mg} \text { or more } \\
\text { had } 1.75 \text { times higher odds of having a lower } \\
\text { MMSE score compared with those receiving } \\
\text { daily dose lower than } 80 \mathrm{mg}\end{array}$ \\
\hline \multirow{3}{*}{$\begin{array}{l}\text { Cancer-related } \\
\text { comorbidities }\end{array}$} & Post-traumatic stress & Hermelink, et al. [18] & $\begin{array}{l}\text { Prospective } \\
\text { longitudinal }\end{array}$ & $\begin{array}{l}\text { Cancer patients exhibited subtle cognitive deficits, } \\
\text { irrespective of chemotherapy, which is mediated } \\
\text { by post-traumatic stress }\end{array}$ \\
\hline & Fatigue & Menning, et al. [13] & $\begin{array}{l}\text { Prospective } \\
\text { longitudinal }\end{array}$ & $\begin{array}{l}\text { Cancer patients exhibited cognitive impairment } \\
\text { prior to receipt of chemotherapy; effect was } \\
\text { mediated by fatigue and not observed when fatigue } \\
\text { accounted for }\end{array}$ \\
\hline & Depression & Polsky, et al. [14] & $\begin{array}{l}\text { Prospective } \\
\text { longitudinal }\end{array}$ & $\begin{array}{l}\text { Hazard Ratio = } 3.55(95 \% \text { CI } 2.79-4.52) \text { for } \\
\text { depressive symptoms within } 2 \text { years following a } \\
\text { cancer diagnosis }\end{array}$ \\
\hline Other & Age-related cognitive decline & $\begin{array}{c}\text { American } \\
\text { Cancer Society [3] }\end{array}$ & Epidemiologic & $\begin{array}{l}47 \% \text { of cancer survivorships in the US is } 70 \text { years } \\
\text { of age or older }\end{array}$ \\
\hline
\end{tabular}

${ }^{\mathrm{a}}$ Mini Mental State Examination. 
In terms of disease-related factors, pretreatment cognitive impairment is a well-established entity not only in chemo-naïve patients but also prior to any intervention whatsoever [10] [11] [12]. The root cause of this phenomenon is unclear, and is likely multifactorial. For example, cancer-related fatigue (CRF), one of the most predominant co-morbidities in oncologic patients, has been shown to correlate with pretreatment cognitive decline, a finding backed by both clinical and neuroimaging data [13]. Psychiatric phenomena might also play a role. The prevalence of depression among patients with many solid cancers exceeds that which is observed in the general population, and cognitive complaints are a core feature in the symptomatology of depressive episodes [14] [15] [16] [17]. Similarly, post-traumatic stress disorder (pTSD) following receipt of a cancer diagnosis is another mediator of cognitive decline in some patients, albeit to a subtle degree [18] [19].

However, in addition to the impact of depression, stress, surgery, medications, age and genetics on cognitive function, evidence confirms the existence of CICD as an independent entity in cancer patients. CICD, defined as both a constellation of subjective symptoms and an empirically-diagnosable entity, impacts patients across disease sites and longitudinally throughout both their treatment and recovery. A better understanding of the risk factors and features of CICD will improve informed consent, patient education, and documentation of outcomes. It is of utmost importance to better characterize and understand this disorder in order to devise treatments that will allow us to improve quality of life for our patients.

\section{Methodology}

In this clinical review, a search for peer-reviewed papers from 1980 to 2019 was performed using the Ovid MEDLINE database using a combination of terms describing cognitive function, chemotherapy, and cancer therapy. In addition, a PubMed search was performed to identify recent papers not currently indexed. References were crosschecked to ensure that all relevant literature was identified and included. A total of 172 papers were reviewed encompassing all study designs, with a special focus on cross-sectional and prospective longitudinal studies evaluating post-chemotherapy cognitive deterioration. After excluding 50 papers, a total of 122 relevant studies were included in this review.

\section{Chemotherapy-Induced Cognitive Dysfunction: Subjective Symptoms versus Clinical Findings}

\section{Self-Reported CICD}

The subjective experience of cognitive deterioration following chemotherapy, herein "self-reported CICD" (SRCICD), first emerged as an important clinical problem during the 1990s in a series of studies based largely on patient interviews [20] [21]. Cognitive complaints included short-term memory loss, trouble concentrating, reduced mental flexibility and speed of information processing, 
visual memory and even a slowing of motor function. More recent studies have found similar results including a 2007 online survey of 471 cancer patients in which $98 \%$ reported changes in cognitive abilities during or after chemotherapy and $92 \%$ reported persistent difficulties with cognitive function after five years [22]. Today, it is evident that the phenomenon, colloquially named "chemo-brain" or "chemo-fog", is experienced by patients across a variety of solid and hematologic malignancies [23]. Of note, the majority of the evidence is in breast cancer (BC) patients who tend to be young and highly functioning and may notice even mild perceived deficits which may limit the generalizability of these studies to cancer patients as a whole.

Estimates of the prevalence of SRCICD have varied substantially across studies (see Table 2) [24]-[33]. One systematic review of twenty-seven studies in BC patients, reported prevalence rates ranging from $21 \%$ to as high as $90 \%$, with the most frequently reported deficits affecting the domains of memory, concentration

Table 2. Self-reported post-chemotherapy cognitive decline by domains affected.

\begin{tabular}{|c|c|c|c|c|c|c|c|c|}
\hline Reference & Study Design & $\begin{array}{l}\text { Exposure } \\
\text { Group }\end{array}$ & $\begin{array}{l}\text { Control } \\
\text { Group }\end{array}$ & Measure & Memory Domain & Attention Domain & $\begin{array}{l}\text { Executive } \\
\text { Function } \\
\text { Domain }\end{array}$ & $\begin{array}{l}\text { General } \\
\text { Cognitive } \\
\text { Impairment } \\
\text { (Domain- } \\
\text { Nonspecific) }\end{array}$ \\
\hline $\begin{array}{l}\text { Schmidt } \\
\text { et al. [24] }\end{array}$ & Cross-sectional & $\begin{array}{c}\text { Various Solid } \\
\text { Malignancies } \\
\text { CH+ } \\
(\mathrm{n}=3108)\end{array}$ & $\mathrm{n} / \mathrm{a}$ & QLACS & $\begin{array}{l}\text { Patients reporting as } \\
\text { abnormal: } 65.4 \%\end{array}$ & $\mathrm{n} / \mathrm{a}$ & $\mathrm{n} / \mathrm{a}$ & $\begin{array}{c}\text { Patient reporting } \\
\text { as abnormal: } \\
45.7 \%\end{array}$ \\
\hline $\begin{array}{l}\text { Schagen } \\
\text { et al. [25] }\end{array}$ & Cross-sectional & $\begin{array}{c}\mathrm{BC} \\
\mathrm{CH}+ \\
(\mathrm{n}=39)\end{array}$ & $\begin{array}{c}\mathrm{BC} \\
\mathrm{CH}- \\
(\mathrm{n}=34)\end{array}$ & $\begin{array}{l}\text { 5-point Likert } \\
\text { scale }\end{array}$ & $\begin{array}{c}\text { Patients reporting as } \\
\text { abnormal: } 31 \%(\mathrm{CH}+) \\
\text { vs } 6 \%(\mathrm{CH}-)(\mathrm{p}=0.007)\end{array}$ & $\begin{array}{l}\text { Patients reporting } \\
\text { as abnormal: } \\
21 \%(\mathrm{CH}+) \text { vs } 3 \% \\
(\mathrm{CH}-)(\mathrm{p}=0.022)\end{array}$ & $\mathrm{n} / \mathrm{a}$ & $\mathrm{n} / \mathrm{a}$ \\
\hline $\begin{array}{l}\text { Downie et } \\
\text { al. [26] }\end{array}$ & Cross-sectional & $\begin{array}{c}\mathrm{BC} \\
\mathrm{CH}+ \\
(\mathrm{n}=21)\end{array}$ & $\mathrm{n} / \mathrm{a}$ & $\begin{array}{l}\text { Semi-structured } \\
\text { interview }\end{array}$ & $\begin{array}{c}\text { Patients reporting as } \\
\text { abnormal: } \% 95\end{array}$ & $\begin{array}{l}\text { Patients reporting } \\
\text { as abnormal: } 90 \%\end{array}$ & $\begin{array}{c}\text { Patients } \\
\text { reporting as } \\
\text { abnormal: } 43 \%\end{array}$ & $\mathrm{n} / \mathrm{a}$ \\
\hline $\begin{array}{c}\text { Shilling et } \\
\text { al. [27] }\end{array}$ & Longitudinal & $\begin{array}{c}\mathrm{BC} \\
\mathrm{CH}+ \\
(\mathrm{n}=142)\end{array}$ & $\mathrm{n} / \mathrm{a}$ & $\begin{array}{l}\text { Semi-structured } \\
\text { interview }\end{array}$ & $\begin{array}{l}\text { Patients reporting as } \\
\quad \text { abnormal: } \\
\text { - } 71 \% \text { at } 6 \text { months } \\
\text { post-treatment } \\
\text { - } 60 \% \text { at } 18 \text { months } \\
\text { post-treatment; }\end{array}$ & $\begin{array}{l}\text { Patients reporting as } \\
\text { abnormal: } \\
\text { - } 64 \% \text { at } 6 \text { months } \\
\text { post-treatment } \\
\text { - } 42 \% \text { at } 18 \text { months } \\
\text { post-treatment }\end{array}$ & $\mathrm{n} / \mathrm{a}$ & $\mathrm{n} / \mathrm{a}$ \\
\hline $\begin{array}{l}\text { Skaali et } \\
\text { al. }[28]\end{array}$ & Cross-sectional & $\begin{array}{c}\text { TC } \\
\text { CH+ } \\
\text { one cycle of } \\
\text { chemotherapy } \\
(\mathrm{n}=38) \text {; two } \\
\text { or more } \\
\text { cycles of } \\
\text { chemotherapy } \\
(\mathrm{n}=53)\end{array}$ & $\begin{array}{c}\mathrm{TC} \\
\mathrm{CH}- \\
(\mathrm{n}=31)\end{array}$ & $\begin{array}{l}\text { Semi-structured } \\
\text { interview }\end{array}$ & $\begin{array}{l}\text { Patients reporting as } \\
\quad \text { abnormal: } \\
-\quad 26 \%(\mathrm{CH}+) \text { vs } 7 \% \\
(\mathrm{CH}-) \text { after one cycle } \\
\text { of chemotherapy ( } \mathrm{p}= \\
0.08) ; \\
-\quad 25 \%(\mathrm{CH}+) \text { vs } 7 \% \\
(\mathrm{CH}-) \text { after two or } \\
\text { more cycles of } \\
\text { chemotherapy } \\
(\mathrm{p}=0.08)\end{array}$ & 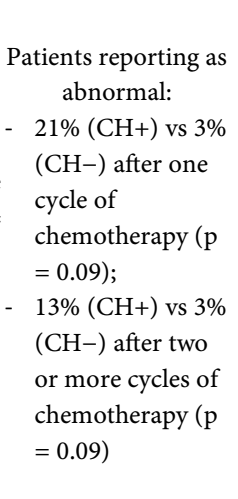 & $\mathrm{n} / \mathrm{a}$ & $\begin{array}{l}\text { Patients reporting } \\
\text { as abnormal: } \\
-29 \%(\mathrm{CH}+) \text { vs } \\
10 \%(\mathrm{CH}-) \\
\text { after one } \\
\text { cycle of } \\
\text { chemotherapy } \\
(\mathrm{p}=0.1) ; \\
-\quad 29 \%(\mathrm{CH}+) \text { vs } \\
10 \%(\mathrm{CH}-) \\
\text { after two or } \\
\text { more cycles of } \\
\text { chemotherapy } \\
\text { (p = 0.1) }\end{array}$ \\
\hline
\end{tabular}




\section{Continued}

\begin{tabular}{|c|c|c|c|c|c|c|c|c|}
\hline $\begin{array}{l}\text { Janelsins } \\
\text { et al. [29] }\end{array}$ & Longitudinal & $\begin{array}{l}\mathrm{BC} \mathrm{CH}+ \\
(\mathrm{n}=580)\end{array}$ & $\begin{array}{c}\text { HC } \\
(n=363)\end{array}$ & $\begin{array}{l}\text { 10-point Likert } \\
\text { scale; modified } \\
\text { MD Anderson } \\
\text { Symptom } \\
\text { Inventory [31] }\end{array}$ & 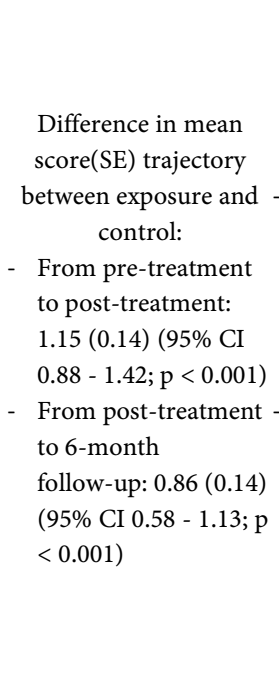 & $\begin{array}{l}\text { Difference in mean } \\
\text { score(SE) trajectory } \\
\text { between exposure } \\
\quad \text { and control: } \\
\text { - From } \\
\text { pre-treatment to } \\
\text { post-treatment: } \\
0.99(0.15)(95 \% \\
\text { CI } 0.7-1.28 ; \mathrm{p}< \\
0.001) \\
\text { - From } \\
\text { post-treatment to } \\
6 \text {-month } \\
\text { follow-up: } 0.52 \\
(0.15)(95 \% \mathrm{CI} \\
0.22-0.81 ; \mathrm{p}< \\
0.001)\end{array}$ & 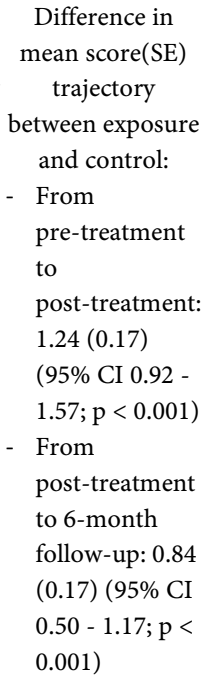 & $\begin{array}{l}\text { : } \\
\\
\end{array}$ \\
\hline $\begin{array}{l}\text { Janelsins } \\
\text { et al. [30] }\end{array}$ & Longitudinal & $\begin{array}{l}\mathrm{BC} \mathrm{CH}+ \\
(\mathrm{n}=581)\end{array}$ & $\begin{array}{c}\mathrm{HC} \\
(\mathrm{n}=364)\end{array}$ & FACT-COG & $\mathrm{n} / \mathrm{a}$ & $\mathrm{n} / \mathrm{a}$ & $n / a$ & $\begin{array}{c}\text { Change in mean } \\
\text { (SD) score from } \\
\text { pre-treatment to } \\
\text { post-treatment: } \\
\text { - } \mathrm{CH}+: \\
-15.9(30.86)(\mathrm{p}< \\
0.001) \\
\text { - } \mathrm{CH}-: \\
+1.4(16.38)(\mathrm{p}= \\
0.122) \\
\text { Change in mean } \\
\text { (SD) score from } \\
\text { pre-treatment to } \\
6-\text { month } \\
\text { follow-up: } \\
-\mathrm{CH}+: \\
-10.4(31.41)(\mathrm{p}< \\
0.001) \\
\text { CH-: } \\
+1.5(16.31)(\mathrm{p}= \\
0.1)\end{array}$ \\
\hline $\begin{array}{l}\text { Kohli et } \\
\text { al. [32] }\end{array}$ & Longitudinal & $\begin{array}{c}\text { Various Solid } \\
\text { Malignancies } \\
\text { CH+; } \\
(\mathrm{n}=595)\end{array}$ & $\mathrm{n} / \mathrm{a}^{*}$ & $\begin{array}{l}11 \text { - point Likert } \\
\text { scale; modified } \\
\text { MD Anderson } \\
\text { Symptom } \\
\text { Inventory [7] }\end{array}$ & $\begin{array}{c}\text { Baseline }=54.5 \% \\
\text { During treatment }= \\
81.8 \% \\
6 \text { months } \\
\text { post-treatment }=76.4 \%\end{array}$ & $\begin{array}{c}\text { Baseline }=55.9 \% \\
\text { During treatment }= \\
85.9 \% \\
6 \text { months } \\
\text { post-treatment }= \\
68.6 \%\end{array}$ & $n / a$ & $\mathrm{n} / \mathrm{a}$ \\
\hline $\begin{array}{l}\text { Tager et } \\
\text { al. [33] }\end{array}$ & Longitudinal & $\begin{array}{c}\mathrm{BC} ; \\
\mathrm{CH}+ \\
(\mathrm{n}=61)\end{array}$ & $\begin{array}{c}\mathrm{BC} ; \\
\mathrm{CH}- \\
(\mathrm{n}=31)\end{array}$ & $\begin{array}{l}\text { 5-Point Likert } \\
\text { Scale }\end{array}$ & $\begin{array}{c}27 \% \text { vs } 32 \% \text { before } \\
\text { treatment; } \\
43 \% \text { vs } 35 \% \text { at } 6 \text { months } \\
\text { post-treatment; } \\
46 \% \text { vs } 31 \% \text { at } 6 \text { months } \\
\text { follow-up }\end{array}$ & $\mathrm{n} / \mathrm{a}$ & $\mathrm{n} / \mathrm{a}$ & $\mathrm{n} / \mathrm{a}$ \\
\hline
\end{tabular}

${ }^{*}$ Compared to patients treated with chemotherapy + radiotherapy, and patients treated with radiotherapy alone, but not to $\mathrm{CH}-$ patients. Abbreviations: $\mathrm{BC}=$ Breast Cancer; $\mathrm{TC}=$ Testicular Cancer; $\mathrm{CH}+=$ have received chemotherapy; $\mathrm{CH}-=$ have not received chemotherapy; HC $=$ Healthy Controls; $\mathrm{QLACS}=$ Quality of Life in Adult Cancer Survivors questionnaire; FACT-COG: Functional Assessment of Cancer Therapy-Cognitive Function.

and executive functioning [34]. One of the largest longitudinal studies to address SRCICD was published in 2016 by Janelsin and colleagues [30]. The study com- 
pared $581 \mathrm{BC}$ patients (stage 1 to $3 \mathrm{c}$ ) who have received chemotherapy with 364 non-cancer controls using the Functional Assessment of Cancer TherapyCognitive Function (FACT-Cog) test pre-treatment, post-treatment and at a six-month follow-up point. In all three testing sessions, chemotherapy-treated BC patients had lower mean FACT-Cog scores compared with controls, indicating greater perceived cognitive deficit. In addition, the $\mathrm{BC}$ group showed an overall decline in the mean scores from pre-treatment to post-treatment, and from pre-treatment to the six-month point, whereas the scores for controls remained stable. Age, race, cognitive reserve, and a higher level of anxiety and depressive symptoms moderated this effect.

A striking illustration of the pervasiveness of SRCICD is the LIVESTRONG survey, an online survey which assessed cancer survivors' post-treatment experience in a variety of domains, including Perceived Cognitive Dysfunction (pCD) [24]. Reportable PCD symptoms included difficulties in concentration, attention span and recall, as well as the subjective experience of suffering from "chemobrain". PCD symptoms were reported by $45.7 \%$ out of 3108 LIVESTRONG respondents harboring diagnoses of BC (29.1\%), testicular cancer (9.1\%), colorectal (5.8\%), prostate (7.4\%), head and neck (3.1\%) and hematological malignancies, over half of which have undergone chemotherapy, which was significantly associated with PCD. In addition, those with depression were more likely to experience cognitive dysfunction.

\section{Diagnosing CICD Using Neuropsychological Testing}

Given the high prevalence of patient-reported cognitive complaints, substantial effort has been put into empirically diagnosing and quantifying CICD, herein called "objectively-verified CICD" (OVCICD). Reports vary significantly in terms of the proportion of patients affected and the cognitive domains involved: some studies have shown marked impairments, most commonly in the domains of memory, attention, concentration, executive function and processing speed; others show only subtle impairments or no impairments at all [35].

The lack of a uniform research methodology seems to account for these inconsistencies. Researchers have employed different study designs (mostly crosssectional, some longitudinal), different control groups (healthy controls versus chemo-naive cancer patients), and different cut-off scores for diagnosing cognitive impairment [36] [37]. They have also timed the testing sessions differently relative to the time when chemotherapy was administered and have employed different testing batteries shown to differ in their respective sensitivity and specificity [38].

In 2011, the lack of consensus on how to investigate OVCICD compelled the International Cognitive and Cancer Task Force (ICCTF) to publish recommendations for standardizing CICD research [39]. In 2012, a meta-analysis of 17 studies looking at 807 patients evaluated neuro-psychologic testing of eight cognitive domains: attention, executive functioning, information processing, motor speed, verbal ability, verbal memory, visual memory, and visuospatial ability [40]. The analysis found that two cognitive domains: verbal and visuospatial ab- 
ilities were most impacted by chemotherapy; verbal ability was worse in BC patients treated with chemotherapy compared to healthy controls, and visuospatial ability was worse compared to chemo-naïve BC patients.

More recently, in 2017 the largest meta-analysis on the matter to date further reinforced the notion that the presence or absence of OVCICD heavily depends on the type of control group used [41]. The study incorporated 2939 BC patients from seventy-two prior studies, both cross-sectional and longitudinal. In an analysis of overall as well as domain-specific cognitive impairment, patients treated with chemotherapy had lower cognitive scores compared to healthy non-cancer controls. Crucially, however, chemotherapy-treated patients performed equally compared with cancer patients not treated with chemotherapy. The analysis strongly suggests that chemotherapy is not a driving factor for cognitive decline in cancer patients, at least as it pertains to its diagnosis using neuropsychological testing.

On the other hand, in a counter argument for the direct culpability of chemotherapy, Collins and colleagues demonstrated a significant dose-response relationship between chemotherapy and objective cognitive decline in a cohort of 60 BC patients, compared to a healthy control group, and after controlling for pre-treatment cognitive baseline [42]. Dose response effect of chemotherapy was also identified in a case cohort study [20]. At two years following chemotherapy completion, cognitive impairment was found in 32\% of the patients treated with high-dose chemotherapy, in $17 \%$ of the patients treated with standard-dose chemotherapy, and in $9 \%$ of the control patients. In comparison with the control patients, patients treated with high-dose chemotherapy appeared to have an 8.2-times higher risk of cognitive impairment (odds ratio; 95\% confidence interval $[\mathrm{CI}]=1.8-37.7)$; in comparison with the patients who received standarddose chemotherapy, this risk of impairment was 3.5-times higher (95\% CI $=1.0$ 12.8).

\section{Neuroimaging}

In contrast to the variable results of neuropsychological testing, imagingbased studies have produced more consistent evidence for an obvious, measurable effect of cytotoxic drugs on the brain. These neuroimaging and the correlating anatomic brain changes have also been documented in early onset dementia syndromes, which present with similar alterations in memory and executive function [43].

Prospective longitudinal magnetic-resonance imaging (MRI) studies show reductions in grey matter volume following chemotherapy [43] [44] [45] [46] [47]. These reductions, noted across multiple regions of the brain including the frontal, parietal, temporal and occipital lobes, occur early in treatment and have been demonstrated to only partially recover over time [46]. White matter changes also occur, including altered neuronal morphology, leukoencephalopathy, gliosis and demyelination [48] [49] [50] [51].

Chemotherapy not only influences the brain's morphology but its hemody- 
namics as well. In a longitudinal follow-up of twenty-seven BC patients using pulsed arterial spin-labeling MRI, significantly increased cerebral perfusion was observed in the right precentral gyrus one month after completing cytotoxic treatment [52]. The authors postulated that this might reflect a compensatory hemodynamic response to treatment-induced neural damage. This increase in perfusion was negatively correlated with pre-treatment cognitive function, suggesting that lower cognitive reserve may be a risk factor for post-treatment cerebral perfusion dysregulation. Similarly, Chen and colleagues reported significant increases in cerebral blood flow across various brain regions following neoadjuvant therapy for $\mathrm{BC}$ which was significantly correlated with reduced performance on various attention tasks [53].

Finally, the apparent structural and hemodynamic changes induced by chemotherapy seem to coincide with functional alterations, as a growing number of functional MRI (fMRI) studies now show. For example, Miao et al. evaluated the long term chemotherapy-related functional changes to the anterior cingulate cortex (ACC) using fMRI in twenty-three chemotherapy-treated BC patients as compared to twenty-six healthy control subjects [54]. The results showed that functional connectivity was significantly lowered in the chemotherapy group and the observed changes were correlated with a reduction in executive function abilities as demonstrated in the Stroop Interference Test. Another study aimed to assess the long-term impact of cisplatin-based chemotherapy on whole-brain networks in testicular cancer patients who were recently orchiectomized [55]. Sixty-four patients underwent baseline and six-month follow-up fMRI imaging and neuro-cognitive testing. Of this cohort, twenty-two subjects were treated with cisplatin and forty-two were under surveillance only. Analysis showed that in patients who had received cisplatin, key connectivity properties of the brain were altered which affect distribution of information across the brain, both on the local as well as the global level [56]. Changes to these measures might reflect suboptimal cognitive abilities and reduced tolerability to local insult, and indeed the imaging findings correlated with poorer overall cognitive performance in the treated group.

\section{A Chasm between SRCICD and OVCICD}

Taken as a whole, the data on OVCICD reveals an obvious discrepancy between patients' subjective experience of CICD, which is often substantial and crippling, and the underwhelming neuropsychological test results. In an illuminating systematic review, Hutchinson and colleagues analyzed 24 prior studies that used objective and subjective measures simultaneously to diagnose CICD in the same cohort. Of the included studies, only eight reported on a significant correlation between the two measures [57]. This finding suggests that SRCICD and OVCICD might be two independent phenomena: some patients have objective cognitive decline which is too subtle to interfere with their daily lives and thus goes unnoticed and unreported; in other patients, the burden of chemotherapy creates the subjective experience of impairment without any measurable 
cognitive deterioration. This self-reported overestimation of cognitive impairment is not at all unique to cancer patients. It has been documented in the context of major depressive disorder, multiple sclerosis, rheumatoid arthritis and HIV, among other conditions [58] [59] [60] [61].

Nevertheless, there is a two-fold rationale for monitoring for SRICD in the post-treatment setting. First, research performed in Alzheimer's disease and vascular dementia indicates that subjective complaints are predictive of measurable cognitive decline at a later stage [62] [63]. Secondly, discrepancies between subjective reporting and objective measurements aside, there is no denying the far-reaching implications of CICD on quality of life. Qualitative data shows that it can diminish patients' self-confidence and self-esteem, undermine their sense of independence and bring about guilt over not being able to maintain their former agency [64]. Another recurring theme is frustration due to what is perceived as lack of acknowledgment of the symptoms by spouses, family members and even the medical team [65]. Furthermore, difficulties in returning to the workplace and in maintaining performance at the necessary level might translate into serious economic impacts for patients, as well [66].

\section{CICD Mechanisms}

The clinical findings, as well as the functional and morphologic brain findings associated with CICD, are most likely the endpoint of multiple mechanisms acting on the brain in synergy. The three most thoroughly developed hypotheses as to the underlying causes are described below.

\section{CICD in the Context of Accelerated Aging}

It has been argued that CICD can best be understood in the broader context of chemotherapy-induced accelerated aging [67]. Evidence pointing to a hastening of the aging process brought about by cancer and/or its treatment is abundant across studies ranging from animal models to epidemiological analyses.

From a clinical standpoint, physiological frailty, which includes cognitive deterioration, can be considered a "physical phenotype" of aging [68]. Interestingly, a study conducted by Ness and colleagues in 2005 has shown frailty to be prevalent in young adult survivors of childhood cancer at a similar rate to that encountered among adults sixty-five years old and above [69]. On the molecular level, chemotherapeutic treatment has been shown to negatively affect several well-identified biological markers of aging [70]. In a recent example, Sanoff et al. prospectively examined the effects of cell senescence marker expression (p16INK4a, ARF mRNA) as well as senescence-associated cytokines in thirty-three women with stage 1 - 3 BC71. Data was collected at four data points: prior to receiving anthracycline-based chemotherapy, immediately upon completing chemotherapy, three months after completing chemotherapy, and finally twelve months after completion of therapy. The analysis showed that expressions of P16INK4a and ARF were elevated immediately after completing chemotherapy, and remained elevated at the twelve-month mark. Interestingly, the absolute increase in the 
expression was $75 \%$ which is equivalent to the increase observed over 14.7 years of chronological aging. In addition, expression of two senescence-associated cytokines (VEGFA and MCP1) was durably increased by adjuvant chemotherapy. In a compelling pre-clinical study, Chiang et al. demonstrated for the first time that treatment of adult mice with cisplatin resulted in a significant increase in endogenous hippocampal clustering of the Tau protein, a phenomenon associated with cognitive decline commonly demonstrated in aging brains [71] [72].

To assert a demonstrable clinical correlation between the changes in biological markers of aging with actual symptomatic cognitive decline, Carroll and colleagues evaluated a cross-sectional cohort of 94 women treated with chemotherapy for early-stage $\mathrm{BC}$ in the previous 3 - 6 years [73]. The group measured the rate of leukocyte DNA damage, peripheral blood mononuclear cell (pBMC) telomere length as a marker of telomerase activity, and the level of tumor necrosis factor receptor 2 (a soluble inflammatory marker), as well as a cognitive function using neuropsychological testing and self-reporting. Higher rates of DNA damage, as well as lower telomerase activity, were related to lower executive function scores. In addition, lower telomerase activity was associated with worse attention and motor speed scores suggesting that biological markers of aging and cognitive decline are related in this chemotherapy-treated cohort.

\section{CICD as a Result of Cytokine Dysregulation}

Many cytotoxic drugs are known to cause dysregulations to the body's cytokine milieu, with significant post-treatment increases observed in the circulating levels of TNF- $\alpha$, IL-1, IL-6, IL-8 and more [74]. An association between these serum cytokine elevations and post-chemotherapy cognitive deteriorations, both objectively measured and self-reported, has been demonstrated repeatedly in clinical studies [75] [76] [77].

The exact mechanism by which peripheral cytokines might be exerting a central negative effect in the CNS has not been elucidated, however, a recent multi-modality study in mice conducted by Shi et al. offers new insight on the matter [78]. Intra-peritoneal injections of docetaxel, adriamycin and cyclophosphamide were administered to healthy mice and the effect of the treatment on the CNS was examined by correlating tissue and serum cytokine levels with cognitive performance using a water maze test, neuronal activity in the hippocampus using manganese-enhanced MRI and the rate of formation and elimination of dendritic spines in the medial prefrontal cortex using transcranial two-photon microscopy. Following treatment, significant elevations in the level of both peripheral and central pro-inflammatory cytokines were recorded, alongside significant reductions in the level of anti-inflammatory cytokines. Crucially, central pro-inflammatory cytokines levels were inversely correlated with cognitive performance, as well as with hippocampal signal intensity as detected by MRI. In addition, central cytokine levels were positively correlated with a marked net loss of dendritic spines, indicating impaired neuroplasticity. This study suggests a direct effect of chemotherapy on central cytokine levels, and a possible mechan- 
ism by which central cytokines might be contributing to CICD. Whether or not peripheral cytokines are also indirectly involved in this process, for example, by stimulating the production of central cytokines, as has been previously suggested, is unclear [74].

\section{Oxidative Stress}

Cytokine disruption is closely linked to another putative mechanism involved in CICD: oxidative stress. The result of an imbalance between the formation and destruction of Reactive Oxygen Species (ROS), oxidative stress has deleterious effects on multiple organ systems [79]. Perhaps most relevant to the discussion concerning CICD, it has been heavily implicated as an important contributor to the development of Alzheimer's disease [80] [81].

Approximately half of all FDA-approved chemotherapeutic drugs generate ROS, either as part of their anti-neoplastic effects or in non-targeted tissues [82]. Among them is the prototypical ROS-generating drug doxorubicin/adriamycin. Extensive research into doxorubicin implicates ROS as not only the plausible mediators of the drug's well-known dose-limiting cardiotoxicity, but also as mediators of CICD in treated cancer survivors [81] [83]. Despite being unable to cross the blood-brain barrier (BBB), doxorubicin has demonstrable neurotoxic properties in the CNS, which are mediated through oxidation of serum proteins and a subsequent elevation in circulating, as well as central levels of the proinflammatory cytokine TNF- $\alpha$ [84] [85]. A high ROS concentration has been shown to lead to a decline in cognitive functions, and is associated with some neurodegenerative disorders and age-dependent decay of neuroplasticity [86].

This mechanism might be shared by other common ROS-generating anti-neoplastic drugs such as cyclophosphamide and methotrexate [87]. It also opens the door to several potential therapeutic targets to prevent ROS-mediated CICD, for example, co-administering anti-TNF antibodies [85]. Animal experiments have shown that doxorubicin-induced oxidative stress is ameliorated by administering 2-mercaptoethan sulfonate sodium (MESNA), an anti-oxidant commonly given to patients as part of drug regimens containing cyclophosphamide or ifosfamide to prevent the occurrence of hemorrhagic cystitis [88].

\section{Susceptibility to CICD}

It is important to know if there are predisposing risk factors for CICD as determination of baseline susceptibility will allow better risk stratification and patient counseling and may alter decisions about treatment choices.

\section{Pharmaco-Genetic Determinants}

Several genetic polymorphisms have been singled out as possible determinants of CICD susceptibility. For example, it has been postulated that patients carrying the Apolipoprotein E (APOE) $\varepsilon 4$ allele, which is an established risk factor for both Alzheimer's disease and PTSD, might be at increased risk for developing CICD [89]. Early reporting by Ahles et al. showed that long-term BC and lymphoma survivors who were treated with chemotherapy and carried the APOE $\varepsilon 4$ 
allele had significantly lower performance in standardized testing for visual memory and spatial ability compared with similar survivors who did not carry the same allele [90]. In a more recent study, testicular cancer survivors who were heterozygous or homozygous for the $\varepsilon 4$ allele and had been treated with BEP (bleomycin, etoposide, cisplatin) performed worse on cognitive tests compared to chemotherapy-treated patients who did not carry the allele [47].

Another avenue of investigation concerns genetic polymorphism which might render the CNS more vulnerable to penetration by intra-venously administered neurotoxic drugs which normally cannot cross into the CNS due to BBB impenetrability [91]. This impermeability to cytotoxic drugs is dependent upon the functioning of local drug transporters, chief among them the P-glycoprotein (p-gp) efflux transporter and the OATP1A2 influx pump [92] [93]. Since many commonly used anti-neoplastic drugs are known substrates of P-gp and OATP1A2, it has been posited that polymorphisms in the genes encoding for these transporters (ABCB1 and SLCO1A2, respectively) might play a role in an individual's susceptibility to CICD [89]. Studies exploring the association between ABCB1 single-nucleotide polymorphisms (SNPs) and chemotherapy induced toxicity have been conflicting, and few studies included CNS toxicity and/or cognitive impairment in their assessments [94]. Of note is a single study by Erdilyi et al. who retrospectively assessed the correlation between chemotherapy-associated encephalopathy and ABCB1 genotypes in 291 acute lymphoblastic leukemia patients [95]. The genotypes of an additional gene in the same ATP-binding cassette transporter family of genes, ABCG2, were also examined. The authors showed that carrying the ABCB1 3435 TT genotype confers a higher risk of treatment-induced encephalopathy, while carrying both a mutated $\mathrm{ABCB} 1$ and a mutated ABCG2 allele results in an even higher risk, suggesting a synergistic effect of the two polymorphisms together. Whether this finding is generalizable to the realm of CICD remains debatable, as there are multiple mutations and genetic polymorphisms in this gene family and further investigation is necessary [96].

\section{Baseline Cognition as a Potential Moderator of CICD}

Cognitive reserve is known to be neuroprotective, as demonstrated by the enhanced recovery from traumatic brain injury and in the slowed trajectory of neurodegenerative disease [97] [98]. It is intuitive to thus assume that a more robust cognitive reserve prior to adjuvant treatment might serve to attenuate OVCICD, however clinical data on this potential effect is lacking. To this end, Ahles et al. longitudinally assessed sixty BC patients with a standardized neuropsychological testing battery before commencing chemotherapy and later at three additional intervals [99]. The researchers found a three-way interaction between receipt of chemotherapy, pre-treatment cognitive reserve (assessed using the proxy of reading ability measured via the Wide Range Achievement Test) and patient age, such that older patients with lower baseline reserve demonstrated impairments to the processing speed domain not exhibited in 
the various control groups (healthy controls, younger patients, chemo-naïve patients).

With regards to a similar interaction between cognitive reserve and SRCICD, the opposite could be expected, namely that well-educated patients with occupations requiring high-level functioning might be more sensitive to even the slightest cognitive changes and thus more likely to report on cognitive symptoms. Interestingly, however, limited evidence suggests that increased cognitive reserve attenuates the subjective perception of CICD [30]. In a longitudinal study using the Functional Assessment of Cancer Therapy-Cognitive Function (FACT-Cog) questionnaire, Janelsins and colleagues found that decreased reserve prior to chemotherapy significantly correlates with lower FACT-Cog scores in BC patients [30]. Similar to the previous study by Ahles et al., baseline reserve was assessed through the proxy of reading ability, using the Wide Range Achievement Test (WRAT) [99].

\section{Future Areas of Investigation}

With the development of targeted chemotherapeutic agents, the potential for novel drug classes to contribute to or worsen chemotherapy induced cognitive dysfunction is real. Emerging therapies such as immunotherapies and targeted therapies will need to be studied to identify any cognitive side-effects in treated patients. Additionally, several pharmacologic and nonpharmacologic interventions have been evaluated as potential therapies for cognitive decline and CICD which may be used as adjuncts during conventional chemotherapeutic treatment.

\section{Emerging CICD Culprits}

Of novel cancer therapies, perhaps the most attention should be paid to immune check point inhibitors (ICIs) for two reasons: first, immune checkpoint blockade is dramatically changing the management of certain malignancies with clinical usage rapidly increasing in these populations; and second, novel severe immune-related adverse events (IrAEs) have already been described in many organs including the CNS after treatment with ICIs, with sometimes fatal results [100] [101].

In one single institution series, $2.4 \%$ of all patients treated with ICIs developed a neurological IrAE, a rate similar to previous reports [101] [102] [103]. Notably, the rate of neurological IrAEs reached $14 \%$ in patients treated with the common regimen of ipilimumab plus nivolumab. However, cognitive dysfunction was not an endpoint of this study and thus how CNS effects from these medications may impact cognition is still unknown and a paucity of additional data exists to guide clinicians. McGinnis et al. showed in their 2017 study that mice treated with a combination of anti-CTLA4 antibody plus CT-guided peripheral irradiation showed impairments in object recognition following treatment [104]. In the clinical setting, Cuzzubbo et al. performed a small-scale feasibility study in which fifteen non-small cell lung cancer and melanoma patients were neurologically assessed prior to commencing ICI treatment (ipilimumab, nivolumab or pembrolizumab) 
and again 3 months later [105]. Performance in two neuropsychological tests (MoCA and TNI-93) remained stable or improved at the three-month mark, with no evidence of cognitive dysfunction due to the treatment in any of the patients. However, further larger-scale prospective studies will be required in order to determine whether or not ICIs exert any influence on cognition. One methodological challenge in future studies will be controlling for the effects of chemotherapy, since many patients exposed to immune checkpoint blockade would have already been treated with often multiple lines of cytotoxic chemotherapy.

\section{Interventions for CICD Prevention and Treatment}

There are currently no FDA-approved drugs for the prevention or treatment of CICD, and no quality data to support the endorsement of any such interventions. However, preliminary clinical and pre-clinic studies have shown promising results, which, at a minimum, should encourage further investigation (see Table 3).

Table 3. CICD interventions under investigation.

Pharmacologic Interventions, Pre-Clinical Studies

\begin{tabular}{|c|c|c|c|}
\hline Reference & $\begin{array}{l}\text { Intervention } \\
\text { Investigated }\end{array}$ & Animal Model & Findings \\
\hline Tangpong et al. [85] & Anti-TNF antibody & $\begin{array}{l}\text { Mice treated with systemic } \\
\text { doxorubicin (intraperitoneal } \\
\text { injection) with/without } \\
\text { anti-TNF antibody }\end{array}$ & $\begin{array}{l}\text { - TNF levels in brain tissue were significantly elevated } \\
\text { following doxorubicin treatment }(\mathrm{p}<0.01) \\
\text { - Measures of brain mitochondrial function were } \\
\text { significantly reduced following doxorubicin treatment } \\
(\mathrm{p}<0.05) \\
\text { - Anti-TNF antibody administration prevented the } \\
\text { increase of central TNF levels, as well as the decline in } \\
\text { mitochondrial function }\end{array}$ \\
\hline Keeney et al. [88] & $\begin{array}{l}\text { 2-mercaptoethanesulfo } \\
\text { nate sodium (MESNA) }\end{array}$ & $\begin{array}{l}\text { Mice treated with systemic } \\
\text { doxorubicin (intraperitoneal - } \\
\text { injection) with/without } \\
\text { MESNA }\end{array}$ & $\begin{array}{l}\text { - Indicators of oxidative stress (protein carbonyl, } \\
\text { protein-bound 4-hydroxynonenal) were significantly } \\
\text { elevated in the sera and brain tissue of mice following } \\
\text { doxorubicin administration (brain: } \mathrm{p}<0.01 \text {; sera: } \mathrm{p}< \\
0.0001 \text { for protein carbonyl, } \mathrm{p}<0.001 \text { for } \\
\text { protein-bound } 4 \text {-hydroxynonenal) } \\
\text { - } \text { Novel Object Recognition (NOR) was significantly } \\
\text { reduced in doxorubicin-treated mice ( } \mathrm{p}<0.05 \text { ) } \\
\text { - MESNA administration before and after doxorubicin } \\
\text { ameliorated the rise of oxidative stress measures in } \\
\text { brain ( }<0.01 \text { ) and sera ( }<<0.01 \text { for protein carbonyl, } \\
\text { p }<0.05 \text { for protein-bound } 4 \text {-hydroxynonenal) } \\
\text { - MESNA administration prevented the doxorubicin- } \\
\text { induced deterioration in NOR }\end{array}$ \\
\hline Zhou et al. [106] & Metformin & $\begin{array}{l}\text { Mice intra-peritoneally } \\
\text { treated with cisplatin } \\
\text { with/without metformin }\end{array}$ & $\begin{array}{l}\text { Exposure to cisplatin significantly reduced } \\
\text { performance in the Novel Object and Place } \\
\text { Recognition Test }(\text { NOPRT) }(\mathrm{p}<0.05) \text {, an effect that } \\
\text { was not exhibited in subjects treated concurrently with } \\
\text { metformin }\end{array}$ \\
\hline
\end{tabular}




\section{Continued}

Chiu et al. [107]

Mesenchymal stem cells (MSC)
Mice intra-peritoneally treated with cisplatin, followed by intra-nasal administration of MSC
- Cisplatin treatment caused deteriorations in executive function, spatial memory and working memory, as measured via the puzzle box test (pBT), the NPORT and the $\mathrm{Y}$-maze test, respectively $(\mathrm{p}<0.05)$.

- Intra-nasal administration of MSC normalized performance levels in the above-described cognitive tests.

Pharmacologic Interventions, Clinical Studies

\begin{tabular}{|c|c|c|c|}
\hline Reference & Study Design & $\begin{array}{l}\text { Intervention } \\
\text { Investigated }\end{array}$ & Study Population \\
\hline $\begin{array}{c}\text { Lawrence et } \\
\text { al. [111] }\end{array}$ & $\begin{array}{c}\text { Randomized, } \\
\text { placebo-controlled } \\
\text { pilot study }\end{array}$ & donepezil & $\begin{array}{c}\text { BC patients }(\mathrm{n}=47) 1-5 \\
\text { years following receipt of } \\
\text { adjuvant chemotherapy }(>4 \\
\text { cycles) }\end{array}$ \\
\hline $\begin{array}{l}\text { Kohli et al. } \\
\quad[112]\end{array}$ & $\begin{array}{l}\text { Open-label } \\
\text { followed by } \\
\text { placebo-controlled } \\
\text { randomization }\end{array}$ & modafinil & $\begin{array}{c}\text { BC patients }(\mathrm{n}=68) \text { who had } \\
\text { previously received } \\
\text { chemotherapy and/or } \\
\text { radiotherapy and have } \\
\text { reported symptoms of } \\
\text { Chemotherapy-Related } \\
\text { Fatigue }(\mathrm{CRF})\end{array}$ \\
\hline
\end{tabular}

$\begin{array}{cc}\begin{array}{c}\text { Lundorff et } \\ \text { al. [113] }\end{array} & \begin{array}{r}\text { Double-blind, } \\ \text { randomized, } \\ \text { cross-over tria }\end{array}\end{array}$

Blackhall et Open-label pilot al. [114] study $\operatorname{armodafinil}^{\star *}$ al. [115] placebo controlled

Randomized, Escalante et double blind, al. [117] placebo-controlled crossover trial methylphenidate

- Patients receiving daily donepezil (5 mg PO for 6 weeks, followed by $10 \mathrm{mg}$ PO for an additional 18 weeks) performed significantly better than placebo in two memory parameters of the Hopkins Verbal Learning Test Revised: Total Recall $(\mathrm{p}=0.033)$ and Discrimination $(\mathrm{p}=0.036)$.

- Phase 1 (open-label): patients who have received modafinil $200 \mathrm{mg}$ PO once daily for 4 weeks in an open-label fashion demonstrated significant improvements in speed of memory $(\mathrm{p}=0.0073)$ and episodic memory $(\mathrm{p}<0.0001)$ compared to baseline. No effect was observed in the domains of attention ( $\mathrm{p}=$ $0.0568)$ and working memory $(\mathrm{p}=0.2475)$.

- Phase 2 (randomized): patients randomized to modafinil showed greater improvements in speed of memory $(\mathrm{p}=0.029)$, episodic memory $(\mathrm{p}=0.0151)$ and continuity of attention $(\mathrm{p}=0.0101)$ compared to placebo.

Patients with various advanced solid malignancies $(\mathrm{n}=36)$, and a tiredness score of $>50 \mathrm{~mm}$ on the Edmonton

Symptoms Assessment System (ESAS).*

26 cancer patients (types unspecified) with a Brief Fatigue Inventory (BFI) score of at least $4^{*}$

Multiple myeloma patients ( = 35) with moderate $\mathrm{CRF}^{*}$

BC patients $(\mathrm{n}=38), 35$ (92.1\%) of which were undergoing chemotherapy or chemotherapy + ET treatment during the study period
Modafinil elicited significantly superior results compared with placebo in two cognitive tests: Finger Tapping Test (FTT) for evaluation of psychomotor speed $(p=0.006)$ and the Trail Making Test (TST) of visual attention and task switching $(\mathrm{p}=0.042)$

- After completing a four-week course of oral modafinil (100 mg daily for two weeks, followed by $200 \mathrm{mg}$ daily for an additional two weeks), patients showed no significant change in performance on the following neurocognitive tests: the Hopkins Verbal Learning Test (HVLT), the Grooved Pegboard Test, the Controlled Oral Word Association Test (COWAT) and the Trail Making Test A.

- Patient receiving oral modafinil (150 mg daily for 56 days) showed no significant improvement compared to placebo in three objective measures of cognitive function (the Trail Making Test-version B, the Symbols Digits Modality Test and the digit span test)

- Methylphenidate-treated patients $(18 \mathrm{mg} /$ day for two weeks) performed significantly better than placebo in the Wechsler Adult Intelligence Scale Digit Span Test $(\mathrm{p}=0.001)$, indicating improved cognitive processing speed. 


\section{Continued}

\section{Behavioral Interventions}

\begin{tabular}{|c|c|c|c|c|}
\hline $\begin{array}{l}\text { Reich et al. } \\
\text { [119] }\end{array}$ & $\begin{array}{l}\text { Randomized, } \\
\text { controlled trial }\end{array}$ & $\begin{array}{l}\text { Mindfulness-Based } \\
\text { Stress Reduction } \\
\quad \text { (MBSR) }\end{array}$ & $\begin{array}{l}\text { BC patients }(\mathrm{n}=322) \\
35.7 \% \text { of which have received } \\
\text { chemotherapy + radiotherapy }\end{array}$ & $\begin{array}{l}\text { Immediately following a six-week MBSR program, no } \\
\text { significant change was observed in cognitive } \\
\text { performance compared with usual care, as measured by } \\
\text { the Everyday Cognition scale (ECog) }\end{array}$ \\
\hline $\begin{array}{c}\text { Dobos et al. } \\
\text { [120] }\end{array}$ & $\begin{array}{l}\text { Prospective } \\
\text { single-arm } \\
\text { cohort study }\end{array}$ & $\begin{array}{l}\text { Mindfulness-Based } \\
\text { Stress Reduction } \\
\quad \text { (MBSR) }\end{array}$ & $\begin{array}{l}\text { Cancer patients }(\mathrm{n}=117) \text {, of } \\
\text { which } 65 \% \text { were diagnosed } \\
\text { with } \mathrm{BC} \text { and } 48.72 \% \text { had } \\
\text { received chemotherapy. }\end{array}$ & $\begin{array}{l}\text { Immediately following an eleven-week MBSR program, } \\
\text { significant improvement was observed in the cognitive } \\
\text { subset of the European organization for research and } \\
\text { treatment of cancer quality of life questionnaire } \\
\text { (EORTC QLQ-C30). }(\mathrm{p}=0.001) \\
\text { Results were sustained at the three-month follow up } \\
\text { period }(\mathrm{p}=0.001)\end{array}$ \\
\hline $\begin{array}{l}\text { Fernandes } \\
\text { et al. [122] }\end{array}$ & $\begin{array}{l}\text { Systematic review of } \\
19 \text { studies } \\
\text { (12 randomized } \\
\text { controlled trials, } 3 \\
\text { non-randomized } \\
\text { controlled trials, } 4 \\
\text { single arm studies). }\end{array}$ & $\begin{array}{c}\text { Cognitive } \\
\text { rehabilitation }\end{array}$ & $\begin{array}{l}\text { Patients with various solid } \\
\text { and hematological } \\
\text { malignancies; } 11 \text { studies } \\
\text { recruited only BC patients; } \\
\text { BC was the most common } \\
\text { diagnosis across all studies. } \\
\text { The vast majority of BC } \\
\text { patients had received prior } \\
\text { chemotherapy. }\end{array}$ & $\begin{array}{l}\text { All included studies found significant improvement in } \\
\text { at least one cognitive domain following a cognitive } \\
\text { rehabilitation intervention, either objectively-assessed } \\
\text { or self-reported. } \\
\text { Objective improvement in memory was the most } \\
\text { frequently reported finding. }\end{array}$ \\
\hline $\begin{array}{l}\text { Oberste et } \\
\text { al. [124] }\end{array}$ & $\begin{array}{l}\text { Single-blinded } \\
\text { randomized } \\
\text { controlled trial }\end{array}$ & $\begin{array}{l}\text { High Intensity Interval } \\
\text { Endurance Training } \\
\text { (HIIT) }\end{array}$ & $\begin{array}{l}\text { BC patients }(\mathrm{n}=59) \text { currently } \\
\text { undergoing first-line } \\
\text { chemotherapy, concurrently } \\
\text { with a HIIT program or a } \\
\text { placebo program (myofascial } \\
\text { release training) }\end{array}$ & $\begin{array}{l}\text { Change in cognitive performance from baseline to the } \\
\text { end of the HIIT intervention will be assessed using the } \\
\text { Hopkins Verbal Learning Test, Controlled Oral Word } \\
\text { Association Test and the Trail-Making-Test }\end{array}$ \\
\hline
\end{tabular}

${ }^{*}$ No information regarding prior chemotherapy treatment; ${ }^{* \star}$ Armodafinil is a levorotatory enantiomer of modafinil; ${ }^{* *}$ Ongoing study, results pending. Abbreviations: BC: breast cancer; CRF: cancer-related fatigue; MESNA: 2-mercaptoethanesulfonate sodium (MESNA); MSC: mesenchymal stem cells; MBSR: Mindfulness-Based Stress Reduction; HIIT: High-Intensity Interval Training.

\section{Pre-Clinical Studies}

As mentioned above, researchers have shown that both anti-TNF antibodies as well as 2-mercaptoethan sulfonate sodium (MESNA) ameliorate the oxidative damage caused by doxorubicin treatment in animal models [85] [88]. In 2016, a group at the MD Anderson Cancer Center used the anti-diabetic drug metformin in mice to successfully prevent cisplatin-induced cognitive deficits in spatial orientation, memory and social discrimination [106]. The drug, which was co-administered together with cisplatin, also helped prevent cisplatin-related morphological abnormalities in the animals' brains, as well as the occurrence of cisplatin-induced peripheral neuropathy. At the same center, a different group using the same cisplatin-induced CICD mouse model demonstrated similar results using nasally-administered mesenchymal stem cells [107]. Stem cell treatment improved cognitive performance related to executive function, spatial recognition and working memory and also reversed a cisplatin-associated decrease in functional neuronal connectivity observed using fMRI.

Most recently, Philpot et al. reported that cyclophosphamide and doxorubicin-induced spatial memory deficits in mice were successfully prevented by 
co-administering the acetylcholine esterase inhibitors donepezil and galantamine together with chemotherapy [108]. Interestingly, the administration of the same drugs after completion of chemotherapy did not prevent the development of these deficits in a separate mice cohort.

\section{Clinical Studies}

Extrapolating from experience with Alzheimer's disease, donepezil has also been evaluated in the clinical setting [109]. In Phase 3, randomized placebo-controlled trial among brain tumor survivors who received radiation, administration of donepezil did not improve patients' overall cognitive scores but did elicit a modest benefit in the domains of memory, dexterity and motor speed [110]. In a pilot study of BC survivors who received prior chemotherapy, daily 5 - $10 \mathrm{mg}$ of oral donepezil improved patients' performance on two memory tests as compared to controls. However, no improvement was demonstrated in other cognitive domains or in self-reporting of cognitive functions [111]. Given this conflicting evidence, further phase 3 trials are required to elucidate the potential role of anti-cholinergic medications in countering CICD symptoms.

Another agent under investigation is modafinil, routinely used as a first-line pharmacologic treatment for narcolepsy-associated daytime sleepiness. In cancer patients, there is some limited evidence for cognitive improvement with modafinil therapy [112] [113]. Kohli et al. administered $200 \mathrm{mg}$ of oral modafinil daily to 76 previously treated $\mathrm{BC}$ patients in an open-label fashion for a period of 4 weeks. Patients with a positive cognitive response as demonstrated by improved memory and attention tests were then randomized to either continuation of modafinil for an additional 4 weeks or placebo. At the completion of the second phase of the study, modafinil was found to significantly improve memory and attention skills compared to placebo [112]. A separate trial evaluated modafinil in the palliative setting for 28 patients with advanced cancer and a high tiredness score. The drug evoked superior performance compared with placebo in two cognitive tests: the Finger Tapping Test (FTT) for evaluation of psychomotor speed, and the Trail Making Test (TST) for assessing visual attention and task switching [113]. Conversely, evaluations of modafinil for cognitive dysfunction as a secondary outcome in two studies of cancer-related fatigue (CRF) found no improvement in any of the administered cognitive tests after treatment [114] [115]. A recent meta-analysis of 19 placebo-controlled trials in non-sleep-deprived adults showed only limited ability of modafinil to improve cognition outside the already established setting of sleep-deprivation [116].

Finally, in 2014, a randomized placebo-controlled crossover trial evaluated the effect of methylphenidate on cognitive performance as a secondary outcome among 33 women with BC undergoing chemotherapy [117]. CRF, the primary endpoint of the study, was not improved by the intervention, however, treated patients performed better on tests of memory, scanning speed, verbal learning and visual perception, suggesting a potential role for methylphenidate in alleviating CICD. 
Non-Pharmacological Interventions

Given the dearth of effective pharmacologic treatments, there has been significant interest in developing behavioral interventions to treat CICD. Efforts to apply mindfulness-based interventions to the problem of CICD has produced some evidence of benefit, however, results across studies are conflicting [118] [119] [120]. Cognitive rehabilitation strategies, aimed at restoring damaged cognitive skills through re-training and the development of compensatory mechanisms, have also been examined, beginning with a pilot study in 2007 which showed initial promise for reversing changes in attention and memory [121]. Encouragingly, 18 subsequent studies including 12 randomized-controlled-trials, showed improvement in at least one cognitive domain after implementing cognitive rehabilitation for CICD patients [121] [122]. Finally, following initial positive results in an animal model, two clinical trials are currently underway investigating the impact of aerobic physical exercise and High-Intensity Interval Training (HIIT) on CICD in patients with acute myeloid leukemia and BC, respectively [123] [124] [125].

\section{Conclusion}

Taken together, the evidence confirms the existence of CICD as a substantial, albeit subtle, clinical issue for cancer patients. However, it is important to rule out other potential causes of cognitive dysfunction. While formal neurocognitive testing might not be sensitive enough to detect CICD, the impact on patients' quality of life is unmistakable and we believe that this merits the inclusion of CICD in any pre-treatment consent discussion in the same way as other better-established risks of chemotherapy. In aiming to improve the quality of life for cancer survivors, we see a need for better measures in two key fields: identifying who is most at risk of developing CICD, and screening for early signs of cognitive deterioration. A third field-prompt intervention is still lacking in actionable data and requires further rigorous investigation.

\section{Conflicts of Interest}

The authors have no disclosures or conflicts of interest.

\section{References}

[1] Bray, F., Ferlay, J., Soerjomataram, I., et al. (2018) Global Cancer Statistics 2018: GLOBOCAN Estimates of Incidence and Mortality Worldwide for 36 Cancers in 185 Countries. CA: A Cancer Journal for Clinicians, 68, 394-424. https://doi.org/10.3322/caac.21492

[2] Siegel, R.L., Miller, K.D. and Jemal, A. (2019) Cancer Statistics, 2019. CA: A Cancer Journal for Clinicians, 69, 7-34. https://doi.org/10.3322/caac.21551

[3] American Cancer Society (2016) Cancer Treatment \& Survivorship Facts \& Figures, 2016-2017. American Cancer Society, Atlanta.

[4] Underwood, E.A., et al. (2019) Cognitive Effects of Adjuvant Endocrine Therapy in Older Women Treated for Early-Stage Breast Cancer: A 1-Year Longitudinal Study. 
Support Care Cancer, 27, 3035-3043. https://doi.org/10.1007/s00520-018-4603-5

[5] Bender, C.M., et al. (2007) Memory Impairments with Adjuvant Anastrozole versus Tamoxifen in Women with Early-Stage Breast Cancer. Menopause, 14, 995-998. https://doi.org/10.1097/gme.0b013e318148b28b

[6] Castellon, S.A., Ganz, P.A., Bower, J.E., Petersen, L., Abraham, L. and Greendale, G.A. (2004) Neurocognitive Performance in Breast Cancer Survivors Exposed to Adjuvant Chemotherapy and Tamoxifen. Journal of Clinical and Experimental Neuropsychology, 26, 955-969. https://doi.org/10.1080/13803390490510905

[7] Van Dyk, K., Crespi, C.M., Bower, J.E., et al. (2019) The Cognitive Effects of Endocrine Therapy in Survivors of Breast Cancer: A Prospective Longitudinal Study up to 6 Years after Treatment. Cancer, 125, 681-689.

https://doi.org/10.1002/cncr.31858

[8] Plas, M., Rotteveel, E., Izaks, G.J., et al. (2017) Cognitive Decline after Major Oncological Surgery in the Elderly. European Journal of Cancer, 86, 394-402.

https://doi.org/10.1016/j.ejca.2017.09.024

[9] Kurita, G.P., Sjorgen, P., Ekholm, O., et al. (2011) Prevalence and Predictors of Cognitive Dysfunction in Opioid-Treated Patients with Cancer: A Multinational Study. Journal of Clinical Oncology, 29, 1297-1303. https://doi.org/10.1200/JCO.2010.32.6884

[10] Ahles, T.A., Saykin, A.J., McDonald, B.C., et al. (2008) Cognitive Function in Breast Cancer Patients Prior to Adjuvant Treatment. Breast Cancer Research and Treatment, 110, 143-152. https://doi.org/10.1007/s10549-007-9686-5

[11] Wefel, J.S., Lenzi, R., Theriault, R.L., et al. (2004) The Cognitive Sequelae of Standard-Dose Adjuvant Chemotherapy in Women with Breast Carcinoma: Results of a Prospective, Randomized, Longitudinal Trial. Cancer, 100, 2292-2299. https://doi.org/10.1002/cncr.20272

[12] Hermelink, K., Untch, M., Lux, M.P., et al. (2007) Cognitive Function during Neoadjuvant Chemotherapy for Breast Cancer: Results of a Prospective, Multicenter, Longitudinal Study. Cancer, 109, 1905-1913. https://doi.org/10.1002/cncr.22610

[13] Menning, S., de Ruiter, M.B., Veltman, D.J., et al. (2015) Multimodal MRI and Cognitive Function in Patients with Breast Cancer Prior to Adjuvant Treatment-The Role of Fatigue. NeuroImage: Clinical, 7, 547-554. https://doi.org/10.1016/j.nicl.2015.02.005

[14] Polsky, D., Doshi, J.A., Marcus, S., et al. (2005) Long-Term Risk for Depressive Symptoms after a Medical Diagnosis. Archives of Internal Medicine, 165, 1260-1266. https://doi.org/10.1001/archinte.165.11.1260

[15] Sotelo, J.L., Musselman, D. and Nemeroff, C. (2014) The Biology of Depression in Cancer and the Relationship between Depression and Cancer Progression. International Review of Psychiatry, 26, 16-30. https://doi.org/10.3109/09540261.2013.875891

[16] MacQueen, G.M. and Memedovich, K.A. (2017) Cognitive Dysfunction in Major Depression and Bipolar Disorder: Assessment and Treatment Options. Psychiatry and Clinical Neurosciences, 71, 18-27. https://doi.org/10.1111/pcn.12463

[17] Culpepper, L., Lam, R.W. and McIntyre, R.S. (2017) Cognitive Impairment in Patients with Depression: Awareness, Assessment, and Management. Journal of Clinical Psychiatry, 78, 1383-1394. https://doi.org/10.4088/JCP.tk16043ah5c

[18] Hermelink, K., Bühner, M., Sckopke, P., et al. (2017) Chemotherapy and PostTraumatic Stress in the Causation of Cognitive Dysfunction in Breast Cancer Patients. Journal of the National Cancer Institute, 109. 
https://doi.org/10.1093/jnci/djx057

[19] Hermelink, K., Voigt, V., Kaste, J., et al. (2015) Elucidating Pretreatment Cognitive Impairment in Breast Cancer Patients: The Impact of Cancer-Related Post-Traumatic Stress. Journal of the National Cancer Institute, 107, PII: djv099. https://doi.org/10.1093/jnci/djv099

[20] Van Damn, F.S., Schagen, S.B., Muller, M.J., et al. (1998) Impairment of Cognitive Function in Women Receiving Adjuvant Treatment for High-Risk Breast Cancer: High-Dose versus Standard-Dose Chemotherapy. Journal of the National Cancer Institute, 90, 210-218. https://doi.org/10.1093/jnci/90.3.210

[21] Schagen, S.B., van Dam, F.S., Muller, M.J., et al. (1999) Cognitive Deficits after Postoperative Adjuvant Chemotherapy for Breast Carcinoma. Cancer, 85, 640-650. https://doi.org/10.1002/(SICI)1097-0142(19990201)85:3<640::AID-CNCR14>3.0.C $\underline{\mathrm{O} ; 2-\mathrm{G}}$

[22] Hurricane Voices Breast Cancer Foundation (2007) Cognitive Deficits Lead to "Loss of Self' among Cancer Patients. Science Daily. http://www.sciencedaily.com/releases/2007/10/071002131248.htm

[23] Edelstein, K.B.L. (2014) Cognitive Dysfunction after Chemotherapy for Breast Cancer. Journal of the International Neuropsychological Society, 20, 351-356. https://doi.org/10.1017/S1355617714000149

[24] Schmidt, J.E., Beckjord, E., Bovbjerg, D.H., et al. (2016) Prevalence of Perceived Cognitive Dysfunction in Survivors of a Wide Range of Cancers: Results from the 2010 LIVESTRONG Survey. Journal of Cancer Survivorship, 10, 302-311. https://doi.org/10.1007/s11764-015-0476-5

[25] Meyers, C.A., Byrne, K.S. and Komaki, R. (1995) Cognitive Deficits in Patients with Small Cell Lung Cancer before and after Chemotherapy. Lung Cancer, 12, 231-235.

[26] Downie, F.P., Mar Fan, H.G., Houédé-Tchen, N., et al. (2006) Cognitive Function, Fatigue, and Menopausal Symptoms in Breast Cancer Patients Receiving Adjuvant Chemotherapy: Evaluation with Patient Interview after Formal Assessment. Psychooncology, 15, 921-930. https://doi.org/10.1002/pon.1035

[27] Shilling, V.J.V. (2007) Self-Reported Cognitive Problems in Women Receiving Adjuvant Therapy for Breast Cancer. European Journal of Oncology Nursing, 11, 6-15. https://doi.org/10.1016/j.ejon.2006.02.005

[28] Skaali, T., Fossa, S.D., Andersson, S., et al. (2011) Self-Reported Cognitive Problems in Testicular Cancer Patients: Relation to Neuropsychological Performance, Fatigue, and Psychological Distress. Journal of Psychosomatic Research, 70, 403-410. https://doi.org/10.1016/j.jpsychores.2010.12.004

[29] Janelsins, M.C., Heckler, C.E., Peppone, L.J., et al. (2018) Longitudinal Trajectory and Characterization of Cancer-Related Cognitive Impairment in a Nationwide Cohort Study. Journal of Clinical Oncology, 36, 3231-3239. https://doi.org/10.1200/JCO.2018.78.6624

[30] Janelsins, M.C., Heckler, C.E., Peppone, L.J., et al. (2016) Cognitive Complaints in Survivors of Breast Cancer after Chemotherapy Compared with Age-Matched Controls: An Analysis from a Nationwide, Multicenter, Prospective Longitudinal Study. Journal of Clinical Oncology, 35, 506-514. https://doi.org/10.1200/JCO.2016.68.5826

[31] Cleeland, C.S., Mendoza, T.R., Wang, X.S., et al. (2000) Assessing Symptom Distress in Cancer Patients: The M.D. Anderson Symptom Inventory. Cancer, 89, 1634-1646. https://doi.org/10.1002/1097-0142(20001001)89:7<1634::AID-CNCR29>3.0.CO;2-V 
[32] Kohli, S., Griggs, J.J., Roscoe, J.A., et al. (2007) Self-Reported Cognitive Impairment in Patients with Cancer. Journal of Oncology Practice, 3, 54-59. https://doi.org/10.1200/JOP.0722001

[33] Tager, F.A., McKinley, P.S., Schnabel, F.R., et al. (2010) The Cognitive Effects of Chemotherapy in Post-Menopausal Breast Cancer Patients: A Controlled Longitudinal Study. Breast Cancer Research and Treatment, 123, 25-34. https://doi.org/10.1007/s10549-009-0606-8

[34] Pullens, M.J., De Vries, J. and Roukema, J.A. (2010) Subjective Cognitive Dysfunction in Breast Cancer Patients: A Systematic Review. Psychooncology, 19, 1127-1138. https://doi.org/10.1002/pon.1673

[35] Vardy, J. and Tannock, I. (2007) Cognitive Function after Chemotherapy in Adults with Solid Tumours. Critical Reviews in Oncology/Hematology, 63, 183-202. https://doi.org/10.1016/j.critrevonc.2007.06.001

[36] van der Wall, E., Nooijen, W.J., Baars, J.W., Holtkamp, N.J., Schorangel, J.H., Richel, D.J., et al. (1995) High-Dose Carboplatin, Thiotepa and Cyclophosphamide (CTC) with Peripheral Blood Stem Cell Support in the Adjuvant Therapy of High-Risk Breast Cancer: A Practical Approach. British Journal of Cancer, 71, 857-862.

[37] Shilling, V., Jenkins, V. and Trapala, I.S. (2006) The (Mis)classification of Chemo-Fog-Methodological Inconsistencies in the Investigation of Cognitive Impairment after Chemotherapy. Breast Cancer Research and Treatment, 95, 125-129.

https://doi.org/10.1007/s10549-005-9055-1

[38] Jansen, C.E., Miaskowski, C.A., Dodd, M.J. and Dowling, G.A. (2007) A Meta-Analysis of the Sensitivity of Various Neuropsychological Tests Used to Detect Chemotherapy-Induced Cognitive Impairment in Patients with Breast Cancer. Oncology Nursing Forum, 34, 997-1005. https://doi.org/10.1188/07.ONF.997-1005

[39] Wefel, J.S., Vardy, J., Ahles, T., et al. (2011) International Cognition and Cancer Task Force Recommendations to Harmonise Studies of Cognitive Function in Patients with Cancer. The Lancet Oncology, 12, 703-708. https://doi.org/10.1016/S1470-2045(10)70294-1

[40] Jim, H.S., Phillips, K.M., Chair, S., et al. (2012) Meta-Analysis of Cognitive Functioning in Breast Cancer Survivors Previously Treated with Standard-Dose Chemotherapy. Journal of Clinical Oncology, 30, 3578-3587. https://doi.org/10.1200/JCO.2011.39.5640

[41] Bernstein, L.J., McCreath, G.A., Komeylian, Z., et al. (2017) Cognitive Impairment in Breast Cancer Survivors Treated with Chemotherapy Depends on Control Group Type and Cognitive Domains Assessed: A Multilevel Meta-Analysis. Neuroscience \& Biobehavioral Reviews, 83, 417-428. https://doi.org/10.1016/j.neubiorev.2017.10.028

[42] Collins, B., MacKenzie, J., Tasca, G.A., et al. (2013) Cognitive Effects of Chemotherapy in Breast Cancer Patients: A Dose-Response Study. Psychooncology, 22, 1517-1527. https://doi.org/10.1002/pon.3163

[43] Quach, C., Hommet, C., Mondon, K., Lauvin, M.A., Cazals, X. and Cottier, J.P. (2014) Early-Onset Dementias: Specific Etiologies and Contribution of MRI. Diagnostic and Interventional Imaging, 95, 377-398. https://doi.org/10.1016/j.diii.2013.07.009

[44] Li, M.C.K. (2018) Longitudinal Assessment of Chemotherapy-Induced Changes in Brain and Cognitive Functioning: A Systematic Review. Neuroscience \& Biobehavioral Reviews, 92, 304-317. https://doi.org/10.1016/j.neubiorev.2018.05.019 
[45] McDonald, B.C., Conroy, S.K., Smith, D.J., et al. (2013) Frontal Gray Matter Reduction after Breast Cancer Chemotherapy and Association with Executive Symptoms: A Replication and Extension Study. Brain, Behavior, and Immunity, 30, S117-S125. https://doi.org/10.1016/j.bbi.2012.05.007

[46] Lepage, C., Smith, A.M., Moreau, J., et al. (2014) A Prospective Study of Grey Matter and Cognitive Function Alterations in Chemotherapy-Treated Breast Cancer Patients. Springerplus, 19, 444. https://doi.org/10.1186/2193-1801-3-444

[47] Amidi, A., Agerbaek, M., Wu, L.M., et al. (2017) Changes in Cognitive Functions and Cerebral Grey Matter and Their Associations with Inflammatory Markers, Endocrine Markers, and APOE Genotypes in Testicular Cancer Patients Undergoing Treatment. Brain Imaging and Behavior, 11, 769-783. https://doi.org/10.1007/s11682-016-9552-3

[48] Matsos, A., Loomes, M., Zhou, I., et al. (2017) Chemotherapy-Induced Cognitive Impairments: White Matter Pathologies. Cancer Treatment Reviews, 61, 6-14. https://doi.org/10.1016/j.ctrv.2017.09.010

[49] Abraham, J., Haut, M.W., Moran, M.T., et al. (2008) Adjuvant Chemotherapy for Breast Cancer: Effects on Cerebral White Matter Seen in Diffusion Tensor Imaging. Clinical Breast Cancer, 8, 88-91. https://doi.org/10.3816/CBC.2008.n.007

[50] Choi, S.M., Lee, S.H., Yang, Y.S., et al. (2001) 5-Fluorouracil-Induced Leukoencephalopathy in Patients with Breast Cancer. Journal of Korean Medical Science, 16, 328-334. https://doi.org/10.3346/jkms.2001.16.3.328

[51] Deprez, S., Amant, F., Smeets, A., et al. (2012) Longitudinal Assessment of Chemotherapy-Induced Structural Changes in Cerebral White Matter and Its Correlation with Impaired Cognitive Functioning. Journal of Clinical Oncology, 30, 274-281. https://doi.org/10.1200/JCO.2011.36.8571

[52] Nudelman, K.N., Wang, Y., McDonald, B.C., et al. (2014) Altered Cerebral Blood Flow One Month after Systemic Chemotherapy for Breast Cancer: A Prospective Study Using Pulsed Arterial Spin Labeling MRI Perfusion. PLoS ONE, 9, e96713. https://doi.org/10.1371/journal.pone.0096713

[53] Chen, X., He, X., Tao, L., et al. (2017) The Attention Network Changes in Breast Cancer Patients Receiving Neoadjuvant Chemotherapy: Evidence from an Arterial Spin Labeling Perfusion Study. Scientific Reports, 17, Article No. 42684. https://doi.org/10.1038/srep42684

[54] Miao, H., Li, J., Hu, S., et al. (2016) Long-Term Cognitive Impairment of Breast Cancer Patients after Chemotherapy: A Functional MRI Study. European Journal of Radiology, 85, 1053-1057. https://doi.org/10.1016/j.ejrad.2016.03.011

[55] Amidi, A., Hosseini, S.M.H., Leemans, A., et al. (2017) Changes in Brain Structural Networks and Cognitive Functions in Testicular Cancer Patients Receiving Cisplatin-Based Chemotherapy. Journal of the National Cancer Institute, 109, djx085. https://doi.org/10.1093/jnci/djx085

[56] Bassett, D.S. and Bullmore, E. (2006) Small-World Brain Networks. Neuroscientist, 12, 512-523. https://doi.org/10.1177/1073858406293182

[57] Hutchinson, A.D., Hosking, J.R., Kichenadasse, et al. (2012) Objective and Subjective Cognitive Impairment Following Chemotherapy for Cancer: A Systematic Review. Cancer Treatment Reviews, 38, 926-934.

https://doi.org/10.1016/j.ctrv.2012.05.002

[58] Srisurapanont, M., Suttajit, S., Eurviriyanukul, K., et al. (2017) Discrepancy between Objective and Subjective Cognition in Adults with Major Depressive Disorder. Scientific Reports, 7, Article No. 3901. https://doi.org/10.1038/s41598-017-04353-w 
[59] Maor, Y., Olmer, L. and Mozes, B. (2001) The Relation between Objective and Subjective Impairment in Cognitive Function among Multiple Sclerosis Patients-The Role of Depression. Multiple Sclerosis, 7, 131-135. https://doi.org/10.1177/135245850100700209

[60] Thames, A.D., et al. (2011) Depression, Cognition, and Self-Appraisal of Functional Abilities in HIV: An Examination of Subjective Appraisal versus Objective Performance. The Clinical Neuropsychologist, 25, 224-243. https://doi.org/10.1080/13854046.2010.539577

[61] Yoon, B.Y., Lee, J.-H. and Shin, S.Y. (2017) Discrepancy between Subjective and Objective Measures of Cognitive Impairment in Patients with Rheumatoid Arthritis. Rheumatology International, 37, 1635-1641. https://doi.org/10.1007/s00296-017-3806-2

[62] Rabin, L.A., Smart, C.M. and Amariglio, R.E. (2017) Subjective Cognitive Decline in Preclinical Alzheimer's Disease. Annual Review of Clinical Psychology, 13, 369-396. https://doi.org/10.1146/annurev-clinpsy-032816-045136

[63] Dufouil, C., Fuhrer, R. and Alperovitch, A. (2005) Subjective Cognitive Complaints and Cognitive Decline: Consequence or Predictor? The Epidemiology of Vascular Aging Study, 53, 616-621. https://doi.org/10.1111/j.1532-5415.2005.53209.x

[64] Henderson, F.M., Cross, A.J. and Baraniak, A.R. (2019) A New Normal with Chemobrain: Experiences of the Impact of Chemotherapy-Related Cognitive Deficits in Long-Term Breast Cancer Survivors. Health Psychology Open, 6. https://doi.org/10.1177/2055102919832234

[65] Boykoff, N., Moieni, M. and Subramanian, S.K. (2009) Confronting Chemobrain: An In-Depth Look at Survivors' Reports of Impact on Work, Social Networks, and Health Care Response. Journal of Cancer Survivorship, 3, 223-232. https://doi.org/10.1007/s11764-009-0098-x

[66] Bolton, G.I.A. (2018) Women's Experiences of Cancer-Related Cognitive Impairment, Its Impact on Daily Life and Care Received for It Following Treatment for Breast Cancer. Psychology, Health \& Medicine, 23, 1261-1274. https://doi.org/10.1080/13548506.2018.1500023

[67] Mandelblatt, J.S., Jacobsen, P.B. and Ahles, T. (2014) Cognitive Effects of Cancer Systemic Therapy: Implications for the Care of Older Patients and Survivors. Journal of Clinical Oncology, 32, 2617-2626. https://doi.org/10.1200/JCO.2014.55.1259

[68] Sternberg, S.A., Schwartz, A.W., Karunananthan, S., et al. (2011) The Identification of Frailty: A Systematic Literature Review. Journal of the American Geriatrics Society, 59, 2129-2138. https://doi.org/10.1111/j.1532-5415.2011.03597.x

[69] Ness, K.K., Krull, K.R., Jones, K.E., et al. (2013) Physiologic Frailty as a Sign of Accelerated Aging among Adult Survivors of Childhood Cancer: A Report from the St Jude Lifetime Cohort Study. Journal of Clinical Oncology, 31, 4496-4503. https://doi.org/10.1200/JCO.2013.52.2268

[70] Maccormick, R.E. (2006) Possible Acceleration of Aging by Adjuvant Chemotherapy: A Cause of Early Onset Frailty? Medical Hypotheses, 67, 212-215. https://doi.org/10.1016/j.mehy.2006.01.045

[71] Sanoff, H.K., Deal, A.M., Krishnamurthy, J., et al. (2014) Effect of Cytotoxic Chemotherapy on Markers of Molecular Age in Patients with Breast Cancer. Journal of the National Cancer Institute, 106, dju057. https://doi.org/10.1093/jnci/dju057

[72] Chiang, A.C.A., Huo, X., Kavelaars, A., et al. (2019) Chemotherapy Accelerates Age-Related Development of Tauopathy and Results in Loss of Synaptic Integrity 
and Cognitive Impairment. Brain, Behavior, and Immunity, 79, 319-325. https://doi.org/10.1016/j.bbi.2019.04.005

[73] Carroll, J.E., Van Dyk, K., Bower, J.E., et al. (2019) Cognitive Performance in Survivors of Breast Cancer and Markers of Biological Aging. Cancer, 125, 298-306. https://doi.org/10.1002/cncr.31777

[74] Wang, X.M., Walitt, B., Saligan, L., et al. (2015) Chemobrain: A Critical Review and Causal Hypothesis of Link between Cytokines and Epigenetic Reprogramming Associated with Chemotherapy. Cytokine, 72, 86-96.

https://doi.org/10.1016/j.cyto.2014.12.006

[75] Lyon, D.E., Cohen, R., Chen, H., et al. (2016) Relationship of Systemic Cytokine Concentrations to Cognitive Function over Two Years in Women with Early Stage Breast Cancer. Journal of Neuroimmunology, 301, 74-82.

https://doi.org/10.1016/j.jneuroim.2016.11.002

[76] Chae, J.W., Ng, T., Yeo, H.L., et al. (2016) Impact of TNF- $\alpha$ (rs1800629) and IL-6 (rs1800795) Polymorphisms on Cognitive Impairment in Asian Breast Cancer Patients. PLoS ONE, 11, e0164204. https://doi.org/10.1371/journal.pone.0164204

[77] Kesler, S., Janelsins, M., Koovakkattu, D., et al. (2013) Reduced Hippocampal Volume and Verbal Memory Performance Associated with Interleukin-6 and Tumor Necrosis Factor-Alpha Levels in Chemotherapy-Treated Breast Cancer Survivors. Brain, Behavior, and Immunity, 30, 109-116. https://doi.org/10.1016/j.bbi.2012.05.017

[78] Shi, D.D., Huang, Y.H., Lai, C.S.W., et al. (2019) Chemotherapy-Induced Cognitive Impairment Is Associated with Cytokine Dysregulation and Disruptions in Neuroplasticity. Molecular Neurobiology, 56, 2234-2243.

https://doi.org/10.1007/s12035-018-1224-4

[79] Pizzino, G., Irrera, N., Cucinotta, M., et al. (2017) Oxidative Stress: Harms and Benefits for Human Health. Oxidative Medicine and Cellular Longevity, 2017, Article ID: 8416763. https://doi.org/10.1155/2017/8416763

[80] Huang, W.J., Zhang, X. and Chen, W.W. (2016) Role of Oxidative Stress in Alzheimer's Disease. Biomedical Reports, 4, 519-522. https://doi.org/10.3892/br.2016.630

[81] Butterfield, D.A. (2014) The 2013 Discovery Award from the Society for Free Radical Biology and Medicine: Selected Discoveries from the Butterfield Laboratory of Oxidative Stress and Its Sequelae in Brain in Cognitive Disorders Exemplified by Alzheimer Disease and Chemotherapy Induced Cognitive Impairment. Free Radical Biology \& Medicine, 157-174. https://doi.org/10.1016/j.freeradbiomed.2014.06.006

[82] Chen, Y., Jungsuwadee, P., Vore, M., et al. (2007) Collateral Damage in Cancer Chemotherapy: Oxidative Stress in Nontargeted Tissues. Molecular Interventions, 7, 147-156. https://doi.org/10.1124/mi.7.3.6

[83] Chatterjee, K., Zhang, J.Q., Honbo, N., et al. (2010) Doxorubicin Cardiomyopathy. Cardiology, 115, 115-162. https://doi.org/10.1159/000265166

[84] Joshi, G., Sultana, R., Tangpong, J., et al. (2005) Free Radical Mediated Oxidative Stress and Toxic Side Effects in Brain Induced by the Anti Cancer Drug Adriamycin: Insight into Chemobrain. Free Radical Research, 39, 1147-1154. https://doi.org/10.1080/10715760500143478

[85] Tangpong, J., Cole, M.P., Sultana, R., et al. (2006) Adriamycin-Induced, TNF-AlphaMediated Central Nervous System Toxicity. Neurobiology of Disease, 23, 127-139. https://doi.org/10.1016/j.nbd.2006.02.013

[86] Beckhauser, T.F., Francis-Oliveira, J. and De Pasquale, R. (2016) Reactive Oxygen Species: Physiological and Physiopathological Effects on Synaptic Plasticity. Journal 
of Experimental Neuroscience, 10, 23-48. https://doi.org/10.4137/JEN.S39887

[87] Gaman, A.M., Uzoni, A., Popa-Wagner, A., et al. (2016) The Role of Oxidative Stress in Etiopathogenesis of Chemotherapy Induced Cognitive Impairment (CICI)“Chemobrain”. Aging and Disease, 7, 307-317. https://doi.org/10.14336/AD.2015.1022

[88] Keeney, J.T.R., Ren, X., Warrier, G., et al. (2018) Doxorubicin-Induced Elevated Oxidative Stress and Neurochemical Alterations in Brain and Cognitive Decline: Protection by MESNA and Insights into Mechanisms of Chemotherapy-Induced Cognitive Impairment (“Chemobrain”). Oncotarget, 9, 30324-30339. https://doi.org/10.18632/oncotarget.25718

[89] Froklage, F.E., Reijneveld, J.C., Heimans, J.J., et al. (2011) Central Neurotoxicity in Cancer Chemotherapy: Pharmacogenetic Insights. Pharmacogenomics, 12, 379-395. https://doi.org/10.2217/pgs.10.197

[90] Ahles, T.A., Saykin, A.J., Noll, W.W., et al. (2003) The Relationship of APOE Genotype to Neuropsychological Performance in Long-Term Cancer Survivors Treated with Standard Dose Chemotherapy. Psychooncology, 12, 612-619.

https://doi.org/10.1002/pon.742

[91] Triarico, S., Maurizi, P., Mastrangelo, S., et al. (2019) Improving the Brain Delivery of Chemotherapeutic Drugs in Childhood Brain Tumors. Cancers (Basel), 11, pii: E824. https://doi.org/10.3390/cancers11060824

[92] Kwan, P. and Brodie, M.J. (2005) Potential Role of Drug Transporters in the Pathogenesis of Medically Intractable Epilepsy. Epilepsia, 46, 224-235.

https://doi.org/10.1111/j.0013-9580.2005.31904.x

[93] Lee, W., Glaeser, H., Smith, L.H., et al. (2005) Polymorphisms in Human Organic Anion-Transporting Polypeptide 1A2 OATP1A2, Implications for Altered Drug Disposition and Central Nervous System Drug Entry. The Journal of Biological Chemistry, 280, 9610-9617. https://doi.org/10.1074/jbc.M411092200

[94] Tulsyan, S., Mittal, R.D. and Mittal, B. (2016) The Effect of ABCB1 Polymorphisms on the Outcome of Breast Cancer Treatment. Pharmacogenomics and Personalized Medicine, 27, 47-58. https://doi.org/10.2147/PGPM.S86672

[95] Erdilyi, D.J., Kamory, E., Csokay, B., et al. (2008) Synergistic Interaction of ABCB1 and ABCG2 Polymorphisms Predicts the Prevalence of Toxicencephalopathy during Anticancer Chemotherapy. The Pharmacogenomics Journal, 8, 321-327. https://doi.org/10.1038/sj.tpj.6500480

[96] Hodges, L.M., Markova, S.M. and Chinn, L.W. (2011) Very Important Pharmacogene Summary: ABCB1 (MDR1, P-Glycoprotein). Pharmacogenet Genomics, 21, 152-161. https://doi.org/10.1097/FPC.0b013e3283385a1c

[97] Steward, K.A., Kennedy, R., Novack, T.A., et al. (2018) The Role of Cognitive Reserve in Recovery from Traumatic Brain Injury. The Journal of Head Trauma Rehabilitation, 33, E18-E27. https://doi.org/10.1097/HTR.0000000000000325

[98] Stern, Y. (2006) Cognitive Reserve and Alzheimer Disease. Alzheimer Disease \& Associated Disorders, 20, 112-117. https://doi.org/10.1097/01.wad.0000213815.20177.19

[99] Ahles, T., Saykin, A.J., McDonald, B.C., et al. (2010) Longitudinal Assessment of Cognitive Changes Associated with Adjuvant Treatment for Breast Cancer: Impact of Age and Cognitive Reserve. Journal of Clinical Oncology, 28, 4434-4440. https://doi.org/10.1200/JCO.2009.27.0827

[100] Inno, A., Metro, G., Bironzo, P., et al. (2017) Pathogenesis, Clinical Manifestations and Management of Immune Checkpoint Inhibitors Toxicity. Tumori Journal, 103, 
405-421. https://doi.org/10.5301/tj.5000625

[101] Spain, L., Walls, G., Julve, M., et al. (2017) Neurotoxicity from Immune-Checkpoint Inhibition in the Treatment of Melanoma: A Single Centre Experience and Review of the Literature. Annals of Oncology, 28, 377-385.

[102] Voskens, C.J., Goldinger, S.M., Loquai, C., et al. (2013) The Price of Tumor Control: An Analysis of Rare Side Effects of Anti-CTLA-4 Therapy in Metastatic Melanoma from the Ipilimumab Network. PLoS ONE, 8, e53745. https://doi.org/10.1371/journal.pone.0053745

[103] Zimmer, L., Goldinger, S.M., Hofmann, L., et al. (2016) Neurological, Respiratory, Musculoskeletal, Cardiac and Ocular Side-Effects of Anti-PD-1 Therapy. European Journal of Cancer, 60, 210-225. https://doi.org/10.1016/j.ejca.2016.02.024

[104] McGinnis, G.J., Friedman, D., Young, K.H., et al. (2017) Neuroinflammatory and Cognitive Consequences of Combined Radiation and Immunotherapy in a Novel Preclinical Model. Oncotarget, 8, 9155-9173. https://doi.org/10.18632/oncotarget.13551

[105] Cuzzubbo, S., Belin, C., Chouahnia, K., et al. (2018) Assessing Cognitive Function in Patients Treated with Immune Checkpoint Inhibitors: A Feasibility Study. Psychooncology, 27, 1861-1864. https://doi.org/10.1002/pon.4725

[106] Zhou, W., Kavelaars, A. and Heijnen, C.J. (2016) Metformin Prevents Cisplatin-Induced Cognitive Impairment and Brain Damage in Mice. PLoS ONE, 11, e0151890. https://doi.org/10.1371/journal.pone.0151890

[107] Chiu, G.S., Boukelmoune, N., Chiang, A.C.A., et al. (2018) Nasal Administration of Mesenchymal Stem Cells Restores Cisplatin-Induced Cognitive Impairment and Brain Damage in Mice. Oncotarget, 9, 35581-35597.

https://doi.org/10.18632/oncotarget.26272

[108] Philpot, R.M., Ficken, M., Johns, B.E., et al. (2019) Spatial Memory Deficits in Mice Induced by Chemotherapeutic Agents Are Prevented by Acetylcholinesterase Inhibitors. Cancer Chemotherapy and Pharmacology, 84, 579-589. https://doi.org/10.1007/s00280-019-03881-8

[109] Birks, J.S. and Harvey, R.J. (2018) Donepezil for Dementia Due to Alzheimer's Disease. Cochrane Database of Systematic Reviews, No. 6, CD001190. https://doi.org/10.1002/14651858.CD001190.pub3

[110] Rapp, S.R., et al. (2015) Donepezil for Irradiated Brain Tumor Survivors: A Phase III Randomized Placebo-Controlled Clinical Trial. JCO, 33, 1653-1659. https://doi.org/10.1200/JCO.2014.58.4508

[111] Lawrence, J.A., et al. (2016) A Study of Donepezil in Female Breast Cancer Survivors with Self-Reported Cognitive Dysfunction 1 to 5 Years Following Adjuvant Chemotherapy. Journal of Cancer Survivorship, 10, 176-184. https://doi.org/10.1007/s11764-015-0463-x

[112] Kohli, S., et al. (2009) The Effect of Modafinil on Cognitive Function in Breast Cancer Survivors. Cancer, 115, 2605-2616. https://doi.org/10.1002/cncr.24287

[113] Lundorff, L., Jønsson, B. and Sjøgren, P. (2009) Modafinil for Attentional and Psychomotor Dysfunction in Advanced Cancer: A Double-Blind, Randomised, CrossOver Trial. Palliative Medicine, 23, 731-738. https://doi.org/10.1177/0269216309106872

[114] Blackhall, L., Petroni, G., Shu, J., Baum, L. and Farace, E. (2009) A Pilot Study Evaluating the Safety and Efficacy of Modafinil for Cancer-Related Fatigue. Journal of Palliative Medicine, 12, 433-439. https://doi.org/10.1089/jpm.2008.0230 
[115] Berenson, J.R., et al. (2015) A Phase 3 Trial of Armodafinil for the Treatment of Cancer-Related Fatigue for Patients with Multiple Myeloma. Support Care Cancer, 23, 1503-1512. https://doi.org/10.1007/s00520-014-2486-7

[116] Kredlow, M.A., Keshishian, A., Oppenheimer, S. and Otto, M.W. (2019) The Efficacy of Modafinil as a Cognitive Enhancer. Journal of Clinical Psychopharmacology, 39, 455-461. https://doi.org/10.1097/JCP.0000000000001085

[117] Escalante, C.P., et al. (2014) A Randomized, Double-Blind, 2-Period, Placebo-Controlled Crossover Trial of a Sustained-Release Methylphenidate in the Treatment of Fatigue in Cancer Patients. The Cancer Journal, 20, 8-14. https://doi.org/10.1097/PPO.0000000000000018

[118] Cifu, G., Power, M.C., Shomstein, S., et al. (2018) Mindfulness-Based Interventions and Cognitive Function among Breast Cancer Survivors: A Systematic Review. BMC Cancer, 18, 1163. https://doi.org/10.1186/s12885-018-5065-3

[119] Reich, R.R., et al. (2017) Mindfulness-Based Stress Reduction in Post-Treatment Breast Cancer Patients: Immediate and Sustained Effects across Multiple Symptom Clusters. Journal of Pain and Symptom Management, 53, 85-95. https://doi.org/10.1016/j.jpainsymman.2016.08.005

[120] Dobos, G., et al. (2015) Integrating Mindfulness in Supportive Cancer Care: A Cohort Study on a Mindfulness-Based Day Care Clinic for Cancer Survivors. Support Care Cancer, 23, 2945-2955. https://doi.org/10.1007/s00520-015-2660-6

[121] Ferguson, R.J., Ahles, T.A., Saykin, A.J., et al. (2007) Cognitive-Behavioral Management of Chemotherapy-Related Cognitive Change. Psychooncology, 16, 772-777. https://doi.org/10.1002/pon.1133

[122] Fernandes, H.A., Richard, N.M. and Edelstein, K. (2019) Cognitive Rehabilitation for Cancer-Related Cognitive Dysfunction: A Systematic Review. Support Care Cancer, 27, 3253-3279. https://doi.org/10.1007/s00520-019-04866-2

[123] Park, H.S., Kim, C.J., Kwak, H.B., et al. (2018) Physical Exercise Prevents Cognitive Impairment by Enhancing Hippocampal Neuroplasticity and Mitochondrial Function in Doxorubicin-Induced Chemobrain. Neuropharmacology, 133, 451-461. https://doi.org/10.1016/j.neuropharm.2018.02.013

[124] Oberste, M., Schaffrath, N., Schmidt, K., et al. (2018) Protocol for the "Chemobrain in Motion Study". CIM Study, a Randomized Placebo-Controlled Trial of the Impact of a High-Intensity Interval Endurance Training on Cancer Related Cognitive Impairments in Women with Breast Cancer Receiving First-Line Chemotherapy. BMC Cancer, 18, 1071. https://doi.org/10.1186/s12885-018-4992-3

[125] Zimmer, P., Oberste, M., Bloch, W., et al. (2016) Impact of Aerobic Exercise Training during Chemotherapy on Cancer Related Cognitive Impairments in Patients Suffering from Acute Myeloid Leukemia or Myelodysplastic Syndrome-Study Protocol of a Randomized Placebo-Controlled Trial. Contemporary Clinical Trials, 49, 1-5. https://doi.org/10.1016/j.cct.2016.05.007 


\section{Abbreviations}

ACC-Anterior Cingulate Cortex

APOE-Apolipoprotienc4 Allele

BBB-Blood-Brain Barrier

$\mathrm{BC}$-Breast Cancer

BEP-Bleomycin, Etoposide, Cisplatin

$\mathrm{CH}+-$ Cancer Patients Receiving Chemotherapy

$\mathrm{CH}--$ Cancer Patients Not Receiving Chemotherapy

CICD-Chemotherapy Induced Cognitive Dysfunction

CRF-Cancer-Related Fatigue

Dox-Doxorubicin

ET-Endocrine Therapy

FACT-Cog-Functional Assessment of Cancer Therapy-Cognitive Function

FMRI-Functional Magnetic Resonance Imaging

GMV-Grey Matter Volume

HC-Healthy Non-Cancer Controls

ICCTF-International Cognitive and Cancer Task Force

ICI-Immune Check Point Inhibitor

MESNA-2-Mercaptoethan Sulfonate Sodium

MRI-Magnetic Resonance Imaging

OV-CICD-Objectively-Verified Chemotherapy Induced Cognitive Dysfunction PBMC-Peripheral Blood Mononuclear Cell

PCD-Perceived Cognitive Dysfunction

SR-CICD-Self-Reported Chemotherapy Induced Cognitive Dysfunction

ROS-Reactive Oxygen Species

TC-Testicular Cancer 